\title{
Theory of the generalized chloride mass balance method for recharge estimation in groundwater basins characterised by point and diffuse recharge
}

\section{N. Somaratne ${ }^{1}$ and K. R. J. Smettem ${ }^{2}$}

${ }^{1}$ South Australian Water Corporation, 250 Victoria Square, Adelaide, 5000 South Australia ${ }^{2}$ Environmental Dynamics and Ecohydrology, School of Environmental System Engineering, University of Western Australia, Crawley, 6009 Western Australia

Received: 25 November 2013 - Accepted: 23 December 2013 - Published: 10 January 2014 Correspondence to: N. Somaratne (nara.somaratne@sawater.com.au)

Published by Copernicus Publications on behalf of the European Geosciences Union.

\section{Generalized chloride \\ mass balance \\ method \\ N. Somaratne and \\ K. R. J. Smettem}

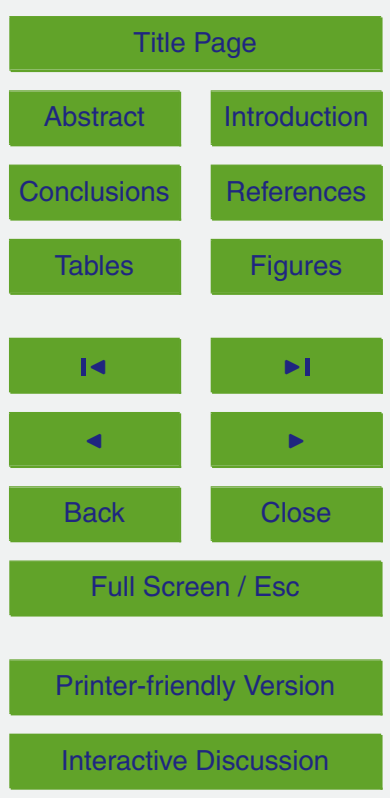




\section{Abstract}

Application of the conventional chloride mass balance (CMB) method to point recharge dominant groundwater basins can substantially under-estimate long-term average annual recharge by not accounting for the effects of localized surface water inputs. This is because the conventional CMB method ignores the duality of infiltration and recharge found in karstic systems, where point recharge can be a contributing factor. When point recharge is present in groundwater basins, recharge estimation is unsuccessful using the conventional $\mathrm{CMB}$ method with, either unsaturated zone chloride or groundwater chloride. In this paper we describe a generalized CMB that can be applied to groundbasins with point recharge. Results from this generalized CMB are shown to be comparable with long-term recharge estimates obtained using the watertable fluctuation method, groundwater flow modelling and Darcy flow calculations. The generalized $\mathrm{CMB}$ method provides an alternative, reliable long-term recharge estimation method for groundwater basins characterised by both point and diffuse recharge.

\section{Introduction}

Sinkholes and other karstic features supply a significant amount of recharge to many carbonate aquifers in temperate and humid regions throughout the world, yet the importance of localised recharge to water balance is relatively poorly understood (Herczeg et al., 1997). For example, in Europe more than $30 \%$ of land surface is made up of karst exposures with more than half the drinking water supply derived from karst aquifers in some countries (Hartmann et al., 2013). Despite its importance, groundwater recharge is probably the most difficult parameter to quantify in karstic settings due to the number of recharge mechanisms operating simultaneously on variable temporal and spatial scales (Leaney and Herczeg, 1995).

The chloride mass balance $(\mathrm{CMB})$ method is one of the most frequently used recharge estimation methods. The fundamental concept of the CMB method is that
HESSD

$11,307-332,2014$

\section{Generalized chloride \\ mass balance \\ method \\ N. Somaratne and \\ K. R. J. Smettem}

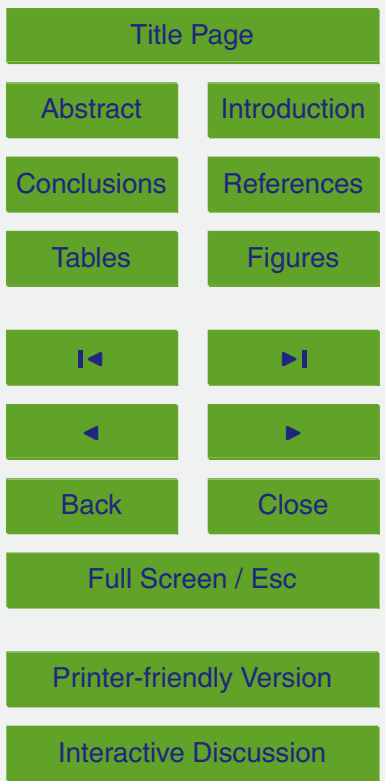


the atmospheric input of chloride in precipitation and dry deposition, concentrates in residual soil water via evapotranspiration processes (Allison and Hughes, 1978; Allison, 1988; Guan et al., 2010). Hence, the conventional CMB essentially estimates diffuse recharge through the soil profile. The CMB method can be applied to a saturated 5 zone (Wood and Sanford, 1995) by measuring groundwater chloride or an unsaturated zone (Walker et al., 1991; Cook et al., 1992) by measuring chloride in soil water. Wood and Sanford (1995) and Wood (1999) highlight the necessary conditions for application of the conventional CMB method, as well as some of its limitations.

Accurate estimation of recharge to aquifers in arid and semi-arid areas remains chal10 lenging, especially where point recharge (recharge from discrete locations) dominates. The main distinctions between karstic and non-karstic aquifers are the duality in porosity, infiltration and recharge. It is these properties of karst systems that generate point recharge and lead to uncertainty in estimated recharge using the conventional CMB method (Somaratne et al., 2013).

In South Australia, the Uley South $\left(113 \mathrm{~km}^{2}\right)$ and Robinson basins $\left(4.7 \mathrm{~km}^{2}\right)$ on the Eyre Peninsula are characterized by significant karst developments in the form of dissolution features, which represent natural discrete points of recharge. In the city of Mount Gambier $\left(26.5 \mathrm{~km}^{2}\right)$ within the Blue Lake capture zone, stormwater is discharged directly to an unconfined aquifer through large sinkholes and 400 drainage wells (EPA, 2007) within an area of $16.8 \mathrm{~km}^{2}$. Drainage wells are discrete recharge points and may be considered as small man-made sinkholes. In the Tatiara catchment, southeast of South Australia, the total creek flow discharges to Poocher Swamp, with the majority of recharge taking place through two sinkholes located in the north-west section of the swamp forming a fresh water bubble of $20 \mathrm{~km}^{2}$ downgradient (Somaratne et al., 2013). When point recharge becomes a contributing recharge mechanism, Somaratne et al. (2013) shown that conventional CMB method requires modification to include both point and diffuse recharge mechanisms.
HESSD

11, 307-332, 2014
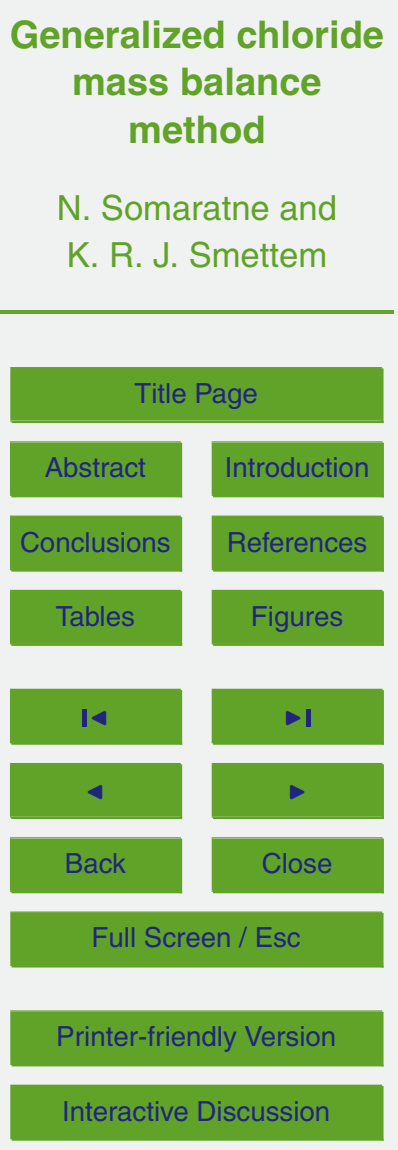
Several modifications to the conventional $\mathrm{CMB}$ equations are presented in the literature. The conventional CMB is expressed as:

$R=\frac{P C_{\mathrm{p}+\mathrm{D}}}{C_{\mathrm{g}}}$

where $R$ is recharge $\left(\mathrm{LT}^{-1}\right), c_{\mathrm{p}+\mathrm{D}}\left(\mathrm{ML}^{-3}\right)$ is the representative mean chloride concen5 tration in rainwater including contributions from dry deposition (Ordens et al., 2012), which is estimated using the empirical formula developed by Hutton (1976), and $c_{\mathrm{g}}$ is chloride concentration in groundwater $\left(\mathrm{ML}^{-3}\right)$ resulting from diffuse recharge which is in equilibrium with unsaturated zone chloride concentration (Walker et al., 1991; Cook et al., 1992). For analysis of recharge in playa basins, Wood and Sanford (1995) modified the conventional CMB equation to include chloride loading from runoff in the mass balance of Eq. (1); this may be written for the unsaturated zone in the form:

$R=\frac{P c_{\mathrm{p}+\mathrm{D}}}{C_{\mathrm{u}}}+\frac{r\left(A_{\mathrm{b}} C_{\mathrm{r}}\right)}{A_{\mathrm{f}} C_{\mathrm{u}}}$

where $r$ is runoff $(\mathrm{L})$ from the basin, $A_{\mathrm{b}}$ is drainage area of the basin $\left(\mathrm{L}^{2}\right), A_{\mathrm{f}}$ is area of the playa lake floor receiving the drainage $\left(\mathrm{L}^{2}\right), c_{\mathrm{r}}$ is average chloride concentration of the runoff $\left(\mathrm{ML}^{-3}\right)$, and $c_{\mathrm{u}}$ is average chloride concentration in the unsaturated zone $\left(\mathrm{ML}^{-3}\right.$ ). Wood et al. (1997) classify the mode of groundwater recharge into interstitial (matrix) and macropore (fractures, cracks, solution features, natural pipes, animal burrows, root tubes and other openings) flow. For application to playa basins with macropore flow, Wood et al. (1997) use an equation of the form:

$20 Q_{\mathrm{tb}}=Q_{\mathrm{mb}}+Q_{\mathrm{ib}}$

where $Q_{\mathrm{tb}}$ is total recharge through the basin floor $\left(\mathrm{L}^{3} \mathrm{~T}^{-1}\right), Q_{\mathrm{mb}}$ is recharge through macropore $\left(\mathrm{L}^{3} \mathrm{~T}^{-1}\right)$, and $Q_{\mathrm{ib}}$ is recharge through interstitial pores $\left(\mathrm{L}^{3} \mathrm{~T}^{-1}\right)$. Wood (1999)
HESSD

11, 307-332, 2014

Generalized chloride

mass balance

method

N. Somaratne and

K. R. J. Smettem

Title Page

Abstract

Introduction

Conclusions

Tables

References

Figures

14

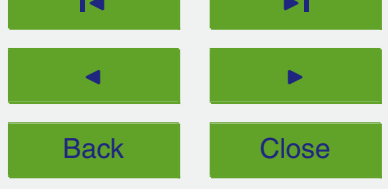

Full Screen / Esc

Printer-friendly Version

Interactive Discussion 
suggests that when macropores are present in the area of investigation, it is generally unsuccessful in using unsaturated core method (using $c_{\mathrm{u}}$ ) to estimate total recharge, implying that the conventional CMB method is valid only when diffuse recharge is the dominant mechanism.

5 Subayani and Sen (2006) modify the conventional CMB equation by taking into account several perceived deficiencies in the methodology. The modified CMB method takes into consideration additional statistical parameters, variances and the correlation coefficient between the variables concerned based on application of the perturbation method.

10 Somaratne et al. (2013) apply the conventional CMB method to calculate total recharge in three groundwater basins characterised by point and diffuse recharge in South Australia. Total recharge obtained from the conventional CMB is smaller than point recharge in the studied basins. Similar observations are found in the recharge studies of Ward et al. (2009) and Ordens et al. (2012). Following Gunn (1983), Ward 15 et al. (2009) adopted a conceptual model of recharge for the Uley South basin that consists of adding runoff to the watertable via numerous sinkholes. Ordens et al. (2012) applied the conventional CMB method to the Uley South basin using measured groundwater chloride. Ward et al. (2009) estimate basin average annual point recharge at $75 \mathrm{~mm}$ and Ordens et al. (2012) estimate total average annual recharge of 53-60 mm.

Because recharge is underestimated by the conventional CMB method in point recharge dominant groundwater basins, we develop a more generalized form of the $\mathrm{CMB}$ that specifically includes both point and diffuse recharge components. We apply conservation of mass, at the ground surface, at the unsaturated zone and at the saturated zone in the derivation of this generalized form of the CMB equation. Consideration of all recharge mechanisms (Gunn, 1983) would introduce undue complexity with little gain, hence only diffuse and point recharge are considered in this analysis. We then apply the generalized $\mathrm{CMB}$ equation to groundwater basins as in Somaratne et al. (2013) and compare this with basin recharge produced by the conventional CMB
HESSD

$11,307-332,2014$
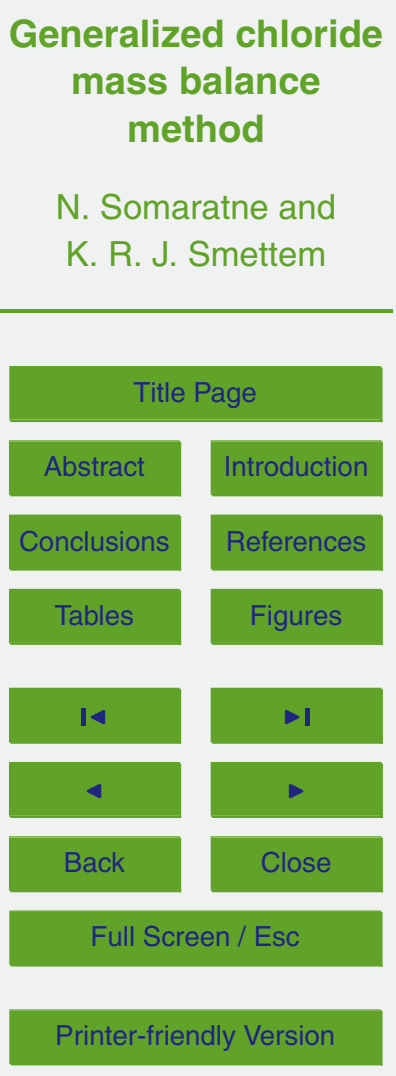

Interactive Discussion 
method. In the more intensively investigated Uley South groundwater basin, we also compare generalized CMB results with other valid methods.

\section{Methods}

\subsection{Description of the study basins and method of parameter estimation}

5 As part of the characterization of point recharge, Somaratne et al. (2013) collated available chloride data suppleneted by additional measurements from three groundwater basins. A detailed description of the basins and method of data collection is found in Somaratne et al. (2013). For brevity, a summary is provided below.

The first study site is the Uley South basin (Fig. 1) located on the Southern Eyre 10 Peninsula of South Australia is approximately $113 \mathrm{~km}^{2}$ in area. The hydrogeology of Uley South basin comprised of Quaternary limestone of an average thickness of $15 \mathrm{~m}$, followed by a Tertiary clay unit of 5-25 m thickness, and a Tertiary sand aquifer (Evans, 1997). The Tertiary clay forms an aquitard between the Tertiary sand and the Quaternary aquifer systems. Groundwater flow direction is from north-east to south-west 15 (Somaratne et al., 2013). Runoff is highly ephemeral, occurring only after moderate to high intensity rainfall and persisting only tens to hundreds of meters before entering a sinkhole (Evans, 1997; Harrington et al., 2006; Ordens et al., 2012). A survey of a $4 \mathrm{~km}^{2}$ area found a density of about one sinkhole per $0.07 \mathrm{~km}^{2}$ of approximate size ranges from $0.4 \mathrm{~m}$ to $2.5 \mathrm{~m}$ diameter (Somaratne, 2013). The second study area is the capture zone of the Blue Lake in the city of Mount Gambier located southeast of South Australia. The Blue Lake is a volcanic crater complex (Fig. 2), is groundwater fed through an extensive karst aquifer and is the water supply reservoir for the city of Mount Gambier (Somaratne et al., 2013). The main source of recharge to the Blue Lake is groundwater from the unconfined, karst Gambier Limestone aquifer underlying the urban area. Average saturated thickness of the Gambier Limestone aquifer is about $60 \mathrm{~m}$. Storm water derived from the central $16.8 \mathrm{~km}^{2}$ of the city area $\left(26.5 \mathrm{~km}^{2}\right)$ is discharged
HESSD

$11,307-332,2014$

Generalized chloride mass balance method

N. Somaratne and K. R. J. Smettem

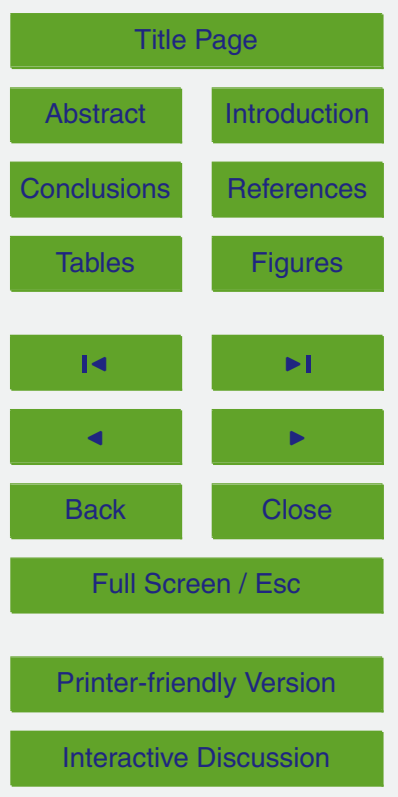


to the unconfined aquifer through three sinkholes and 400 storm water drainage wells (Somaratne et al., 2013). The third case study reported by Somaratne et al. (2013) is the Poocher Swamp's fresh water bubble, which is the largest of fresh water plumes that float on brackish water in the area, is a result of flows from Tatiara Creek which 5 enter Poocher Swamp (Fig. 3). The major recharge is through two sinkholes located in the north-west section of the swamp (Somaratne et al., 2013). The area encompassed by the $1000 \mathrm{mg} \mathrm{L}^{-1}$ salinity contour comprises approximately $20 \mathrm{~km}^{2}$. The unconfined aquifer is Murray Group Limestone and contains brackish water with average TDS (total dissolved solids) $>1400 \mathrm{mgL}^{-1}$, with a chloride concentration of $>500 \mathrm{mg} \mathrm{L}^{-1}$

10 (MacKenzie, 2013). Saturated thickness of the limestone unconfined aquifer is approximately $50-60 \mathrm{~m}$.

Additional data collected by Somaratne et al. (2013) include water samples from surface runoff from Tatiara creek, Poocher Swamp, and from storm runoff to drainage wells from Mount Gambier for chloride analysis. In addition, groundwater samples were 15 collected from diffuse and point recharge dominant zones of the three study basins to supplement existing data and fill data gaps. Selected sampling wells are away from brackish water upward leakage sites and the swamp in Uley South basin and historically known contaminated sites in Mount Gambier.

Three approaches were used for quantifying surface runoff to point recharge sources. For the Uley South basin, runoff estimation is based on the study of Ward et al. (2009). Ward et al. (2009) used LEACHM (Hutson 2003), a variably saturated model of the soil profile that uses the curve number approach described by Williams (1991) to estimate surface runoff. The model considers four surface cover scenarios, catchment slope, vegetation cover, potential evapotranspiration, and four soil and subsoil profiles as key variables. According to Ward et al. (2009) timing and magnitude of recharge from steeply sloped sites is relatively independent of vegetation type and cover. The LEACHM modelling result is critically dependent on the assumption that all runoff becomes recharge via sinkholes. The simulations were not sensitive to the four soil and sub-soil profiles. The only profile that showed a slight difference was the

HESSD

$11,307-332,2014$
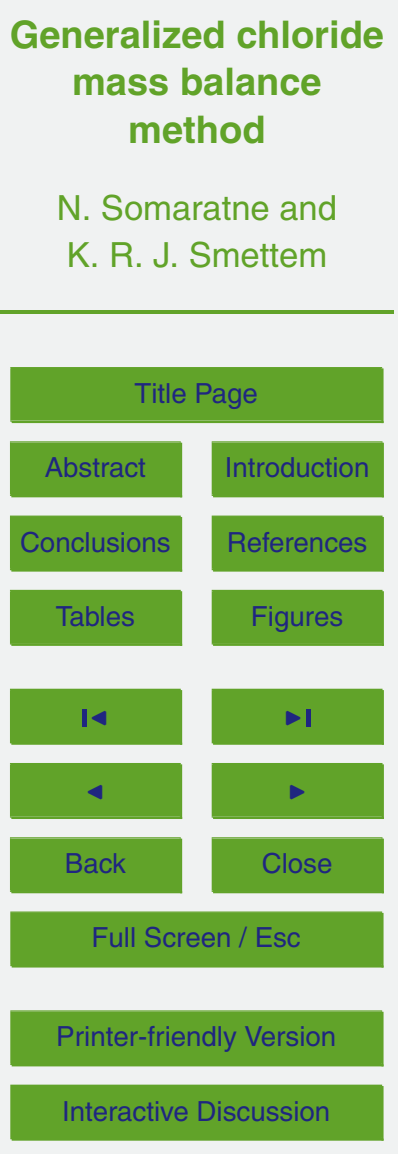

Interactive Discussion 
profile with $300 \mathrm{~mm}$ of soil on calcrete. This site showed a tendency for slightly less runoff, than the other soil profiles. In general, however, the four profiles considered did not lead to significant differences in recharge hence, the recharge value obtained is the average over the four soil profiles.

$5 \quad$ For the Mount Gambier urban catchment, Nguyen (2013) used the urban storm water model MUSIC (2009) to quantify storm water runoff using daily rainfall and pan evaporation. This model considers rainfall threshold for the impervious area, soil moisture storage and field capacity, and infiltration coefficient for the pervious area to calculate runoff. A sensitivity analysis indicates field capacity of the soil had the greatest effect 10 on runoff from the pervious area (Nguyen, 2013). In the Nguyen study, MUSIC modelled rainfall and runoff processes for the period 2007-2012 using a daily time step with daily rainfall and evaporation data. For sub-catchments with drainage wells, average percentage of impervious ( $51 \%$ ) and pervious ( $49 \%)$ areas was determined using digital maps of the city using Geographic Information System (GIS) tools. A rainfall 15 threshold of $1 \mathrm{~mm}$ was used for impervious areas. Uniform soil storage capacity and field capacity values of 120 and $80 \mathrm{~mm}$ were used for the pervious areas. The initial soil storage capacity was set to $30 \%$ (Nguyen, 2013). The average annual runoff volume from both pervious and impervious areas were calculated as point recharge to drainage wells and three sinkholes.

In Poocher Swamp, surface water is present intermittently, usually from midwinter to early spring (July-September). Swamps tend to form in shallow, low-lying depressions where there is clay topsoil. Water in the swamps does not become saline, therefore it must be partially open to leakage to groundwater (Herczeg et al., 1997). The major outflow is drainage through two sinkholes located in the north-west section of the swamp.

Chloride concentrations of groundwater near the Poocher Swamp sinkhole (about 20$40 \mathrm{mgL}^{-1}$ ) are much lower than those in regional groundwaters $\left(300-500 \mathrm{mg} \mathrm{L}^{-1}\right)$. This indicates input of low chloride swamp water (about $28 \mathrm{mg} \mathrm{L}^{-1}$ ) directly into the groundwater system adjacent to the swamp (Herczeg et al., 1997; Somaratne, 2011a) creating a freshwater plume.
HESSD

$11,307-332,2014$
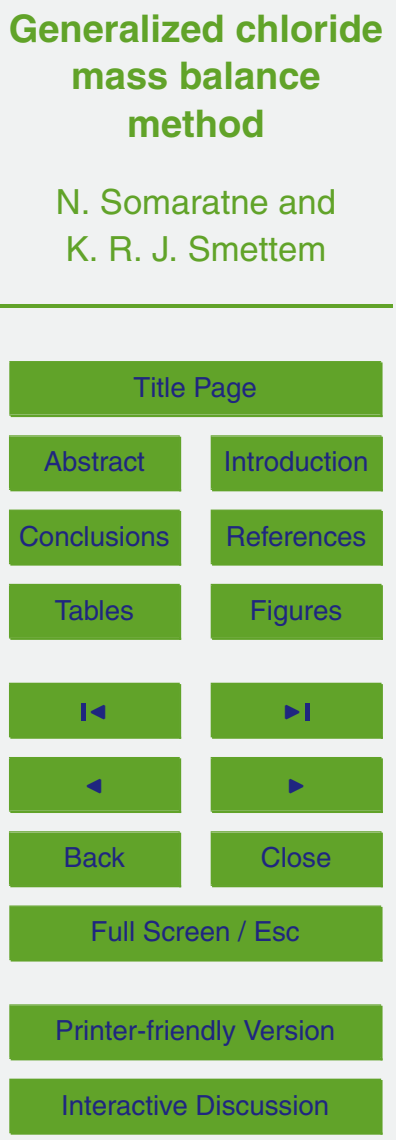
To illustrate the above concept, Somaratne (2011b) investigated this phenomenon in small sub-catchments $\left(0.03-0.12 \mathrm{~km}^{2}\right)$ discharging storm water to drainage wells in the city of Mount Gambier. Thus, drainage wells are used to measure chloride concentration in the aquifer at discrete recharge points, due to their location in a karstic limestone 5 aquifer similar to the Uley South basin. As one might expect in karstic systems, the hydraulic parameters obtained from pumping tests indicate a high degree of heterogeneity. In Uley South, transmissivity ranged from 3000 to $13000 \mathrm{~m}^{2}$ day $^{-1}$ and with specific yields from 0.03 to 0.72 (Evans, 1997) with a basin average of 0.25-0.3 (Davis, personal communication, 2012; Davis et al., 2012) for the Quaternary Limestone aquifer. 10 In the Blue Lake capture zone, transmissivity is in the range of $450-24000 \mathrm{~m}^{2}$ day $^{-1}$ and specific yield is $0.1-0.4$ for the Gambier Limestone aquifer (Mustafa and Lawson, 2002). These small pockets of fresher water around point recharge sources, which result from surface water entering the aquifer bypassing the soil matrix, affect the CMB, and hence estimated recharge. It is not possible to measure chloride in fresh water pockets around solution features such as sinkholes in Uley South because the depth, extent and distribution of flow paths in the karst is poorly understood, and is likely to remain unknown.

Water samples were taken from drainage wells and aquifer monitoring wells at three depth intervals in the Gambier Limestone unconfined aquifer. Ten surface runoff samples, 21 samples from drainage wells and 21 samples from monitoring wells were collected. Measured mean chloride concentrations with standard deviation at stormwater entry points to drainage wells, within drainage wells, and at water level monitoring wells, are given in Fig. 4. This example illustrates that the chloride concentration in aquifer monitoring wells differs from the chloride concentration in fresh water pockets at or 25 near drainage wells.

\subsection{Derivation of a general form of the CMB equation}

If it is possible to account for the mass of chloride in the system, the mode of transport of chloride from the land surface to groundwater becomes irrelevant. In karst aquifers,
HESSD

$11,307-332,2014$
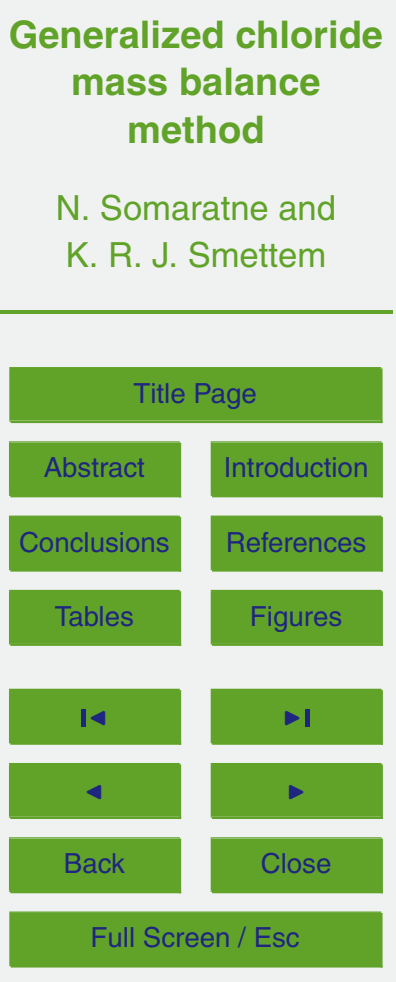

Printer-friendly Version

Interactive Discussion 
this is an impossible task (Somaratne et al., 2013). The chloride concentration at the discrete recharge points remains close to the surface water concentration, and elsewhere remains close to the diffuse recharge groundwater chloride concentration.

The conventional CMB equation derived by Nyagawambo (2006) is modified in this 5 work to include point recharge. Following the conceptual model developed for the Uley South basin (Somaratne et al., 2013), duality of recharge is considered in the development of a generalized CMB. The method integrates chloride mass balance from the ground surface to the saturated zone in a control volume as shown in Fig. 5.

In this model, sinkholes connected to the watertable bypass the soil zone, directly 10 recharging the aquifer as point recharge. The unconnected sinkholes add runoff deeper into the unsaturated zone, which then rapidly drains into the watertable by mechanisms described by Gunn (1983). A system approach is adopted, in which the hydrologic function of each primary component: ground surface, vadoze zone and saturated zone is considered separately as an integral part of a whole system (Taylor and Greene, 15 2001).

Following Nyagawambo (2006), the chloride mass balance at the soil surface can be written:

$\frac{\Delta\left(s_{\mathrm{s}} c_{\mathrm{s}}\right)}{\Delta t}=P c_{\mathrm{p}+\mathrm{D}}-\left(Q_{\mathrm{p}}+Q_{\mathrm{o}}+F\right) c_{\mathrm{s}}$

Note that $Q_{\mathrm{p}}$ and $Q_{\mathrm{o}}$ are expressed as depths of the catchment. Following Nyagawambo (2006), assumptions are made to simplify Eq. (4). The storage fluctuation term may be assumed to be negligible relative to inflows and outflows, if the time of integration is sufficiently long to cover several hydrological years (Nyagawambo, 2006). Water is assumed to evaporate in its pure form and therefore no chloride is lost through evaporative fluxes. It is also assumed that the chloride concentration in surface flows at the point of runoff generation and the point of infiltration remains the same as in surface water. For a negligible change in chloride concentration at the soil surface, Eq. (4) reduces to:

$F C_{\mathrm{s}}=P c_{\mathrm{p}+\mathrm{D}}-\left(Q_{\mathrm{p}}+Q_{\mathrm{o}}\right) c_{\mathrm{s}}$
HESSD

$11,307-332,2014$

Generalized chloride

mass balance

method

N. Somaratne and

K. R. J. Smettem

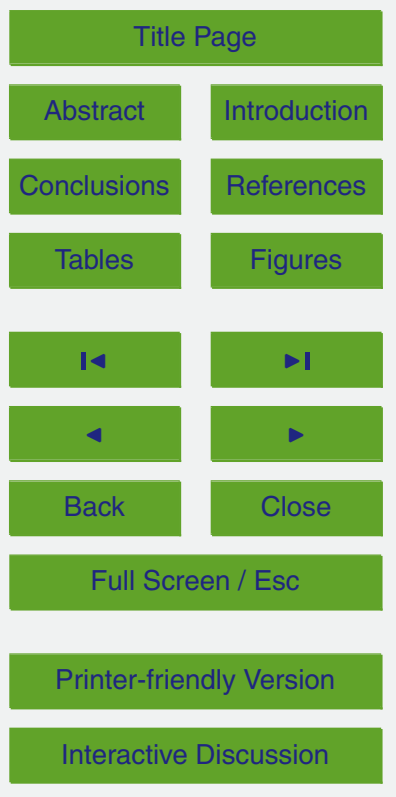


Similarly, the application of chloride mass balance to the unsaturated zone yields:

$\frac{\Delta\left(s_{\mathrm{u}} c_{\mathrm{u}}\right)}{\Delta t}=F c_{\mathrm{s}}-R_{\mathrm{u}} c_{\mathrm{u}}$

The upper boundary of the unsaturated zone is taken to be the ground surface with an infiltration rate $F$, and the lower boundary of the unsaturated zone is taken to be the wa5 tertable with recharge rate $R_{\mathrm{u}}$. The unsaturated zone storage fluctuation term may then be assumed to be negligible if the time of integration is selected to be long enough to cover several hydrological years (Nyagawambo, 2006). It is also assumed that the loss of chloride through transpiration from the unsaturated zone is negligible and that the catchment is not subject to major land use changes. The above assumptions reduce 10 Eq. (6) to:

$F C_{\mathrm{s}}-R_{\mathrm{u}} c_{\mathrm{u}}=0$

Combining Eqs. (5) and (7) and rearranging them gives:

$R_{\mathrm{u}} c_{\mathrm{u}}=\left(\left(P c_{\mathrm{p}+\mathrm{D}}\right)-\left(Q_{\mathrm{p}}+Q_{\mathrm{o}}\right) c_{\mathrm{s}}\right)$

Rearranging Eq. (8) yields:

$R_{\mathrm{u}} c_{\mathrm{u}}+Q_{\mathrm{p}} c_{\mathrm{s}}=\left(P c_{\mathrm{p}+\mathrm{D}}\right)-Q_{\mathrm{o}} c_{\mathrm{s}}$

Chloride equilibrium at both the ground surface and in the unsaturated zone is required for conventional CMB application (Guan et al., 2010). As pointed out in Scanlon et al. (2002), these assumptions are usually taken to imply a constant chloride profile below the root zone. Similarly, chloride mass balance can be applied to the saturated zone across the watertable; with the upper boundary as the point and diffuse recharge and the lower boundary as the impermeable base of the saturated zone. This implies that groundwater chloride in the saturated zone is derived only from recharge and that there is no chloride loss from the saturated zone through evapotranspiration. It is also

Generalized chloride

mass balance

method

N. Somaratne and

K. R. J. Smettem

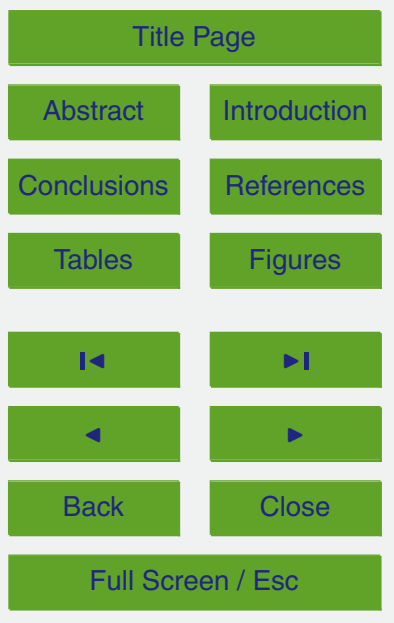

Printer-friendly Version

Interactive Discussion 
assumed that steady-state groundwater flow prevails, where lateral fluxes, and upward and downward leakages do not result in changes in chloride concentration, and there is no irrigation water recycling or waste water irrigation. Using the above assumptions, groundwater chloride in the saturated zone is determined only by the diffuse and point 5 recharge fluxes crossing the watertable. Thus, the CMB for the saturated zone is:

$$
\frac{\Delta\left(s_{\mathrm{g}} c_{\mathrm{g}}\right)}{\Delta t}=\left(R_{\mathrm{u}} c_{\mathrm{u}}+Q_{\mathrm{p}} c_{\mathrm{s}}\right)-\left(R_{\mathrm{u}} c_{\mathrm{gd}}+Q_{\mathrm{p}} c_{\mathrm{s}}\right)
$$

where $c_{\mathrm{s}} \leq c_{\mathrm{g}} \leq c_{\mathrm{gd}}$. For long-term equilibrium, $c_{\mathrm{u}}$ is equal to $c_{\mathrm{gd}}$ (Walker et al., 1991; Cook et al., 1992; Wood, 1999; Scanlon et al., 2002). The first term $\left(R_{\mathrm{u}} C_{\mathrm{u}}+Q_{\mathrm{p}} c_{\mathrm{s}}\right)$ on the right-hand side (RHS) is total initial chloride mass of recharge fluxes in the system prior to crossing the watertable plane. The second term $\left(R_{\mathrm{u}} C_{\mathrm{gd}}+Q_{\mathrm{p}} c_{\mathrm{s}}\right)$ on the RHS is chloride mass after $R_{\mathrm{u}}$ and $Q_{\mathrm{p}}$ cross the watertable plane at the end of $\Delta t$. For steady chloride mass in storage (aquifer), the change in chloride mass in groundwater storage is negligible. Equation (10) is combined with Eq. (9) and rearranged to yield, for closed basins where $Q_{0}=0$ :

$R_{\mathrm{u}}=\frac{\left(P c_{\mathrm{p}+\mathrm{D}}\right)\left[1-\left\{\frac{Q_{\mathrm{p}} c_{\mathrm{s}}}{P c_{\mathrm{p}+\mathrm{D}}}\right\}\right]}{C_{\mathrm{gd}}}$

The term $Q_{\mathrm{p}} C_{\mathrm{s}} /\left(P C_{\mathrm{p}+\mathrm{D}}\right)$ on the RHS is the weighting factor for point recharge $\left(w_{\mathrm{p}}\right)$, and $w_{\mathrm{u}}=\left(1-w_{\mathrm{p}}\right)$ is the weighting factor for diffuse recharge. In this way, total chloride mass derived from rainfall-runoff is partitioned between point and diffuse recharge. Total recharge $(R)$ is $R=R_{\mathrm{u}}+Q_{\mathrm{p}}$; hence:

$R=\frac{w_{\mathrm{u}}\left(P c_{\mathrm{p}+\mathrm{D}}\right)}{c_{\mathrm{gd}}}+\frac{w_{\mathrm{p}}\left(P c_{\mathrm{p}+\mathrm{D}}\right)}{c_{\mathrm{s}}}$

When $100 \%$ diffuse recharge takes place $\left(w_{\mathrm{p}}=0\right)$ and $c_{\mathrm{gd}}=c_{\mathrm{g}}$, Eq. (12) becomes the conventional CMB equation given in Eqs. (1) and (13a). Similarly, when $100 \%$ point
HESSD

$11,307-332,2014$

Generalized chloride

mass balance

method

N. Somaratne and

K. R. J. Smettem

Title Page

Abstract

Introduction

Conclusions

Tables

References

Figures

14

$>1$

$\triangleleft$

Back

Close

Full Screen / Esc

Printer-friendly Version

Interactive Discussion 
recharge takes place, diffuse recharge goes to zero $\left(w_{u}=0\right)$, and Eq. (12) becomes point recharge, $Q_{\mathrm{p}}$, given in Eq. (13b). For coupled point and diffuse recharge, substituting $w_{\mathrm{p}}$ and $w_{\mathrm{u}}$ into Eq. (12) and further simplifying to yield Eq. (13c):

$R=\frac{P C_{\mathrm{p}+\mathrm{D}}}{C_{\mathrm{gd}}}$

$5=\frac{P c_{\mathrm{p}+\mathrm{D}}}{C_{\mathrm{s}}}=Q_{\mathrm{p}}$

$R=\frac{\left(P c_{\mathrm{p}+\mathrm{D}}\right)+Q_{\mathrm{p}}\left(c_{\mathrm{gd}}-c_{\mathrm{s}}\right)}{c_{\mathrm{gd}}}$

A special case occurs where ambient groundwater chloride concentration is much higher than the chloride concentration of surface runoff, $c_{\mathrm{gd}} \gg c_{\mathrm{s}}$, and then $\left(c_{\mathrm{g}}-\right.$ $\left.{ }_{10} c_{\mathrm{s}}\right) / c_{\mathrm{g}} \approx 1$, thus Eq. (13c) yields:

$R=\frac{P C_{\mathrm{p}+\mathrm{D}}}{C_{\mathrm{gd}}}+Q_{\mathrm{p}}$

Equation (13d) is the same as Eq. (3), with recharge expressed in depth $\left(L T^{-1}\right)$ rather than volume $\left(\mathrm{L}^{3} \mathrm{~T}^{-1}\right)$. Thus Eq. (3) is a special case of the generalized CMB.

\section{Results and discussion}

15 For estimation of recharge using generalized CMB method, data on $P, c_{\mathrm{p}+\mathrm{D}}, c_{\mathrm{s}}, c_{\mathrm{gd}}$ and $Q_{p}$ are from Somaratne et al. (2013). For Uley South basin, Ward et al. (2009) obtained runoff of basin equivalent depth using LEACHM model flowing through sinkholes to the watertable. Runoff in Uley South is short lived hence $c_{\mathrm{s}}$ is taken as $c_{\mathrm{p}+\mathrm{D}}$ (Ordens et al., 2012) calculated from Hutton (1976). Diffuse recharge chloride is taken as

\section{HESSD}

$11,307-332,2014$

Generalized chloride

mass balance

method

N. Somaratne and

K. R. J. Smettem

Title Page

Abstract

Introduction

Conclusions

Tables

References

Figures

14

4

Back

Full Screen / Esc

Printer-friendly Version

Interactive Discussion
I

\section{ose}


an average of monitoring wells located close to the inland boundary where there are no karstic features present. For Mount Gambier in the Blue Lake capture zone, $Q_{\mathrm{p}}$ is taken from Nguyen (2013) for an average annual rainfall of $750 \mathrm{~mm}$. Basin equivalent depth of point recharge through drainage wells was then calculated for a catchment area of $516.8 \mathrm{~km}^{2}$. Chloride in rainfall was estimated using Hutton (1976) and surface runoff was measured using 10 samples collected within the city. Based on Tatiara Creek annual flow for the period 1980-2010, average annual point recharge is estimated to be equivalent depth of $125 \mathrm{~mm}$ over the fresh water bubble $\left(20 \mathrm{~km}^{2}\right)$. Poocher Swamp water samples were collected for $c_{\mathrm{s}}$, and $c_{\mathrm{p}+\mathrm{D}}$ was estimated using Hutton (1976). Chloride 10 in diffuse recharge zone was taken from the nearest monitoring well outside the fresh water bubble. Input parameters used for recharge estimation using generalized CMB are given in Table 1.

Recharge to the Uley South basin and Mount Gambier in the Blue Lake capture zone are estimated using Eq. (13c), and for the Poocher Swamp fresh water bubble, where $15 C_{\mathrm{S}} \ll c_{\text {gd }}$, Eq. (13d) is used. A comparison of generalized CMB estimated recharge to conventional CMB estimated recharge (Somaratne et al., 2013) is provided in Table 2.

Conventional CMB estimated recharge is approximately 2, 5 and 9 fold lower than the generalized CMB estimated recharge for Uley South, Blue Lake capture zone and Poocher Swamp freshwater bubble respectively. Similar observations were made by Wood et al. (1997) in their study on macropore recharge in playa basins. Wood et al. (1997) report macro pore recharge flux ranges between 60 and $80 \%$ of total recharge and concluded that if the recharge in playa floors is calculated with only the conventional chloride mass balance method or the tritium method, the recharge is severely underestimated because of the presence of macro pores.

25 Generalized CMB estimated recharge is at the lower end of the more intensively investigated recharge in the Uley South basin. In this basin, Ordens et al. (2012) reported a basin average annual recharge estimate using the watertable fluctuation method (WTF) at $129 \mathrm{~mm}$, taking a basin average specific yield of 0.25 ; average annual recharge of $146 \mathrm{~mm}$ obtained from transient calibration of a groundwater model
HESSD

11, 307-332, 2014
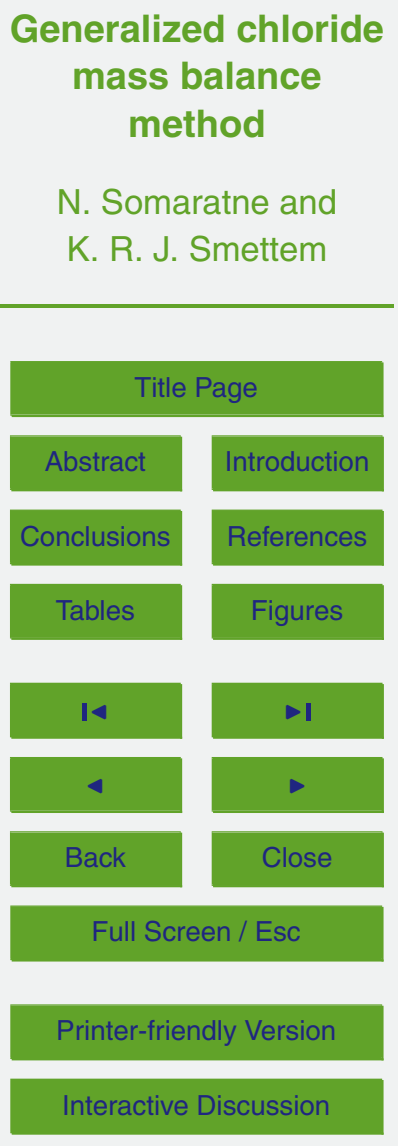
(Werner, 2010) is based on MODFLOW (McDonald and Harbough, 1988) and PEST (Watermark Numerical Computing, 2004); and $157 \mathrm{~mm}$ long-term average recharge value of the Eyre Region Water Resources Planning Committee (2000) is based on Darcy flow and water balance calculations of Evans (1997). However, generalized CMB 5 estimated recharge is significantly higher than conventional CMB estimated average annual recharge of 53-60 mm (Ordens et al., 2012), 52-71 mm (SA Water unpublished data) and $71 \mathrm{~mm}$ (Evans, 1997) for the basin. This higlights the fact that application of the conventional CMB method to estimate total recharge in groundwater basins characterised by point and diffuse recharge is unsuccessful, either using unsaturated or 10 saturated zone chloride as inputs. Thus generalized CMB provides an alternative reliable method for recharge estimation in karstic settings.

\section{Conclusions}

Sinkholes in depressions are an important source of point recharge to limestone aquifers. Application of the conventional $\mathrm{CMB}$ method to point recharge dominant groundwater basins substantially under estimates long-term average recharge by not accounting for the effect of localized surface water inputs. For application of the generalized $\mathrm{CMB}$, obtaining diffuse recharge groundwater chloride is critical to accuracy. Groundwater chloride measurements should be obtained away from fresh water pockets or plumes created by point recharge or soil-water chloride should be extracted from the unsaturated zone above the watertable in order to obtain diffuse zone chloride. Quantification of runoff at the catchment or sub-catchment levels is required for accurate assessment of point recharge and to apply the generalized CMB equation for total recharge estimation. For this purpose, many available watershed models provide runoff estimates as part of an overall water balance. A comparison of the modified CMB results with the long-term recharge estimates obtained using the WTF method, groundwater flow modelling and Darcy flow calculations, shows slightly less but comparable results. Hence the generalized CMB method augments the conventional CMB method
HESSD

$11,307-332,2014$

\section{Generalized chloride mass balance method \\ N. Somaratne and K. R. J. Smettem}

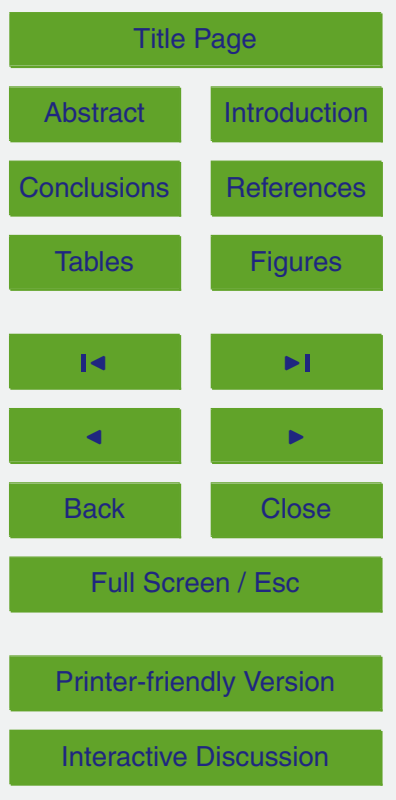


by accounting for point recharge that by-passes the unsaturated zone and thus provides an alternative, reliable, long-term recharge estimation method for groundwater basins with point and diffuse recharge mechanisms.

Acknowledgements. The authors thank Prof. Wolfgang Kinzelbach for valuable comments 5 made on the earlier version of this paper, which helped to improve the manuscript.

\section{References}

Allison, G. B.: A review of some physical, chemical and isotopic techniques available for estimating groundwater recharge, in: Estimation of Natural Groundwater Recharge, edited by: Simmers, I., D. Reidel Publishing Co., Dordrecht, 509 pp., 49-72, 1988.

Allison, G. B. and Hughes, M. W.: The use of environmental chloride and tritium to estimate total recharge to an unconfined aquifer, Aust. J. Soil Res., 16, 181-195, 1978.

Cook, P. G., Edmunds, W. M., and Gaye, C. B.: Estimating paleo-recharge and paleo-climate from unsaturated zone profiles, Water Resour. Res., 28, 2721-2731, 1992.

Davis, A., Cahill, K., Hatch, M., and Munday, T.: Aquifer characterisation in the Uley South basin, South Australia, using NMR: Final Report, CSIRO Technical Report EP-31-01-12-14, Water for a Healthy Country National Research Flagship, CSIRO, Australia, 2012.

EPA: EPA Guidelines for stormwater management in Mount Gambier, Environment Protection Authority, South Australia, 2007.

Evans, S. L.: Estimating long-term recharge in unconfined carbonate aquifers using conventional and environmental isotope techniques - Eyre Peninsula, South Australia, M.S. thesis, Flinders Unversity of South Australia, unpublished, 1997.

Eyre Region Water Resources Planning Committee: Water allocation plan southern basins prescribed wells area, Government of South Australia, through Department of Water Resources, South Australia, 2000.

25 Guan, H., Love, A. J., Simmons, C. T., Hutson, J., and Ding, Z.: Catchment conceptualisation for examining applicability of chloride mass balance method in an area with historical forest clearance, Hydrol. Earth Syst. Sci., 14, 1233-1245, doi:10.5194/hess-14-1233-2010, 2010.

Gunn, J.: Point-recharge of limestone aquifers - a model from New Zealand karst, J. Hydrol., 61, 19-29, 1983.
HESSD

$11,307-332,2014$
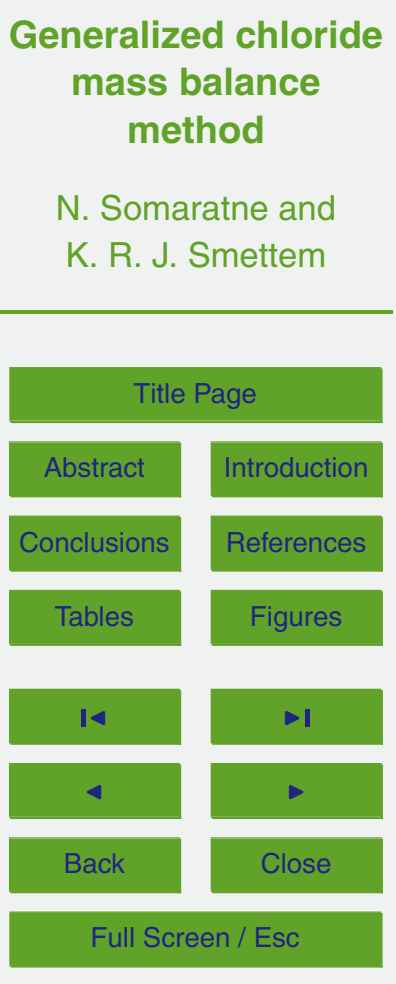

Printer-friendly Version

Interactive Discussion 
Hartmann, A., Weiler, M., Wagener, T., Lange, J., Kralik, M., Humer, F., Mizyed, N., Rimmer, A., Barberá, J. A., Andreo, B., Butscher, C., and Huggenberger, P.: Process-based karst modelling to relate hydrodynamic and hydrochemical characteristics to system properties, Hydrol. Earth Syst. Sci., 17, 3305-3321, doi:10.5194/hess-17-3305-2013, 2013.

5 Herczeg, A. L., Leaney, F. W. J., Stadter, M. F., Allan, G. L., and Fifield, L. K.: Chemical and isotope indicators of point-source recharge to a karst aquifer, South Australia, J. Hydrol., 192, 271-299, 1997.

Hutson, J. L.: LEACHM - a process-based model of water and solute movement, transformations, plant uptake and chemical reactions in the unsaturated zone, version 4, Research Series No. R03-1, Department of Crop and Soil Sciences, Cornell University, Ithaca, New York, 2003.

Hutton, J. T.: Chloride in rainwater in relation to distance from the ocean, Search, 7, 207-208, 1976.

Leaney, F. W. and Herczeg, A. L.: Regional recharge to a karst aquifer estimated from chemical 15 and isotopic composition of diffuse and localised recharge, South Australia, J. Hydrol., 164, 363-387, 1995.

McDonald, M. G. and Harbough, B. R.: A modular three-dimensional finite difference groundwater flow model, Techniques of Water Resources Investigations of the United States Geological Survey, Book 6, Geological Survey Open File Report 91-536, USGS, Reston, Virginia 20192, 1988.

MUSIC.: Model for Urban Stormwater Improvement Conceptualisation (MUSIC), MUSIC Development Team, eWater CRC, Australia, 2009.

Mustafa, S. and Lawson, J. S.: Review of tertiary aquifer properties, Gambier Limestone, Lower South-East, South Australia, South Australia Department of Water, Land and Biodiversity 25 Conservation Report, DWLBC 2002/24, unpublished, 2002.

Nguyen, K.: Estimating the annual stormwater yield in the Blue Lake capture zone, South Australia, M.S. thesis, University of South Australia, unpublished, 2013.

Nyagawambo, N. L.: Groundwater recharge estimation and water resources assessment in a crystalline basement aquifer, Ph.D. thesis, Delft University of Technology, A. A. Balkema Publishers, Delft, the Netherlands, 2006.

Ordens, C. M., Werner, A. D., Post, V. E. A., Hutson, J. L., Simmons, C. T., and Irvine, B. M.: Groundwater recharge to a sedimentary aquifer in the topographically closed Uley South basin, South Australia, Hydrogeol. J., 20, 61-72, doi:10.1007/s10040-011-0794-2, 2012.

\section{Generalized chloride \\ mass balance \\ method \\ N. Somaratne and \\ K. R. J. Smettem}

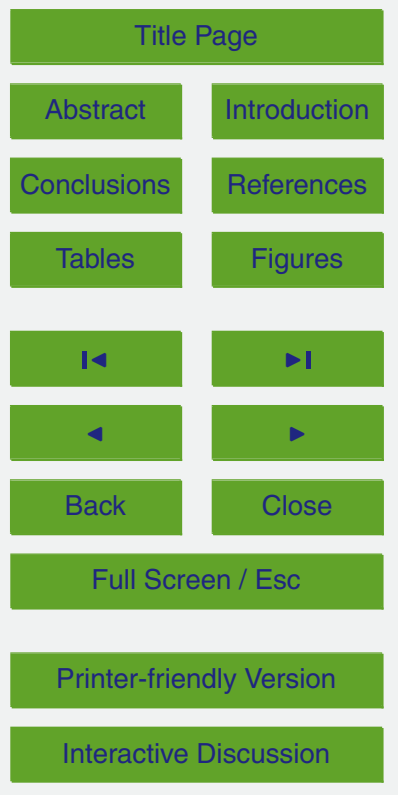


Scanlon, B. R., Healy, R. W., and Cook, P. G.: Choosing appropriate techniques for quantifying groundwater recharge, Hydrogeol. J., 10, 18-39, doi:10.1007/s10040-001-0176-2, 2002.

Somaratne, N.: Mapping Poocher Swamp fresh water bubble, Internal Project Briefing Report, South Australian Water Corporation, South Australia, 2011a.

5 Somaratne, N.: Salinity profiling and chloride measurement in storm water discharge drainage wells in Blue lake capture zone, Internal Project Briefing Report, South Australian Water Corporation, South Australia, 2011b.

Somaratne, N.: Hydrogeology of the Uley South Basin, SA Water 2013/1, South Australian Water Corporation, South Australia, 2013.

10 Somaratne, N., Smettem, K., Lawson, J., Nguyen, K., and Frizenschaf, J.: Hydrological functions of sinkholes and characteristics of point recharge in groundwater basins, Hydrol. Earth Syst. Sci. Discuss., 10, 11423-11449, doi:10.5194/hessd-10-11423-2013, 2013.

Subayani, A. and Sen, Z.: Refined chloride mass balance method and its application in Saudi Arabia, Hydrol. Process., 20, 4373-4380, doi:10.1002/hyp.6172, 2006.

15 Taylor, C. J. and Greene, E. A.: Quantitative approaches in characterizing karst aquifers, US Geological Survey Karst Insterest Group Proceedings, Water Resources Investigation Report 01-4011, 164-166, 2001.

Walker, G. R., Jolly, I. D., and Cook, P. G.: A new chloride leaching approach to the estimation of diffuse recharge following a change in landuse, J. Hydrol., 128, 49-67, 1991.

Ward, J. D., Hutson, J., Howe, B., Fildes, S., Werner, A. D., and Ewenz, C.: A modelling framework for the assessment of recharge processes and climate change, Report developed through the Eyre Peninsula Groundwater allocation and Planning Project, Eyre Peninsula Natural Resources Management Board, Government of South Australia, 2009.

Watermark Numerical Computing: PEST-Model independent parameter estimation, User Manual, 5th edn., available at: http://www2.epa.gov/sites/production/files/documents/PESTMAN. PDF (last access: 9 January 2014), 2004.

Werner, A. D.: A groundwater model of Uley South Basin, South Australia, Flinders University of South Australia, unpublished, 2010.

Williams, J. R.: Runoff and water erosion, in: Modelling Plant and Soil Systems, edited by: Hanks, J. and Ritchie, J. T., Agronomy Monograph 31, American Society of Agronomy, Madison, Wisconsin, chap. 18, 439-455, 1991.

Wood, W. W.: Use and misuse of the chloride mass balance method in estimating groundwater recharge, Ground Water, 37, 2-3, 1999.

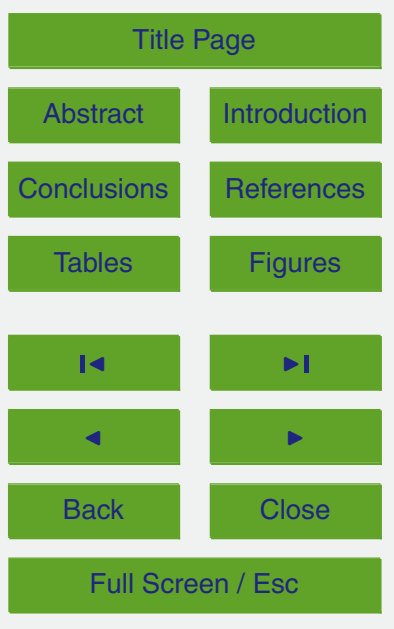


Wood, W. W. and Sanford, W. E.: Chemical and isotopic methods for quantifying groundwater recharge in a regional semi-arid environment, Ground Water, 33, 458-468, 1995.

Wood, W. W., Raqinwater, K. R., and Thompson, D. B.: Quantifying macropore recharge: examples from a semi-arid area, Ground Water, 35, 1097-1106, 1997.

Generalized chloride

mass balance

method

N. Somaratne and

K. R. J. Smettem

Title Page

Abstract

Introduction

Conclusions

References

Tables

Figures

14

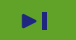

4

Back

Close

Full Screen / Esc

Printer-friendly Version

Interactive Discussion 
Table 1. Input parameters for the recharge estimation using generalized CMB.

\begin{tabular}{lccccc}
\hline $\begin{array}{l}\text { Groundwater } \\
\text { Basin }\end{array}$ & $\begin{array}{c}\text { Average } \\
\text { annual } \\
\text { rainfall } \\
\left(\mathrm{mmyr}^{-1}\right)\end{array}$ & $\begin{array}{c}\text { Chloride in } \\
\text { rainfall } \\
\left(\mathrm{mgL}^{-1}\right)\end{array}$ & $\begin{array}{c}\text { Chloride in } \\
\text { surface } \\
\text { runoff } \\
\left(\mathrm{mgL}^{-1}\right)\end{array}$ & $\begin{array}{c}\text { Chloride in } \\
\text { diffuse } \\
\text { recharge } \\
\text { zone }\left(\mathrm{mgL}^{-1}\right)\end{array}$ & $\begin{array}{c}\text { Point } \\
\text { recharge } \\
\left(\mathrm{mmyr}^{-1}\right)\end{array}$ \\
\hline Uley South & 550 & 14.2 & 14.2 & 147 & 75 \\
\hline $\begin{array}{l}\text { Blue Lake } \\
\text { capture zone }\end{array}$ & 750 & 8.5 & 12.7 & 63 & 390 \\
\hline $\begin{array}{l}\text { Poocher } \\
\begin{array}{l}\text { Swamp fresh } \\
\text { water bubble }\end{array}\end{array}$ & 450 & 3.1 & 28 & 550 & 125 \\
\hline
\end{tabular}

Generalized chloride

mass balance

method

N. Somaratne and

K. R. J. Smettem

Title Page

Abstract

Introduction

Conclusions

References

Tables

Figures

14

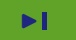

4

Back

Close

Full Screen / Esc

Printer-friendly Version

Interactive Discussion 


\section{HESSD}

$11,307-332,2014$

Generalized chloride

mass balance

method

Table 2. Comparison of generalized and conventional CMB estimated recharge. Recharge volume in $\mathrm{m}^{3}$ is given in brackets.

\begin{tabular}{lcc}
\hline Groundwater basin & $\begin{array}{c}\text { Recharge using } \\
\text { generalized CMB } \\
\left(\mathrm{mmyr}^{-1}\right)\end{array}$ & $\begin{array}{c}\text { Recharge using } \\
\text { conventional CMB } \\
\left(\mathrm{mmyr}^{-1}\right)\end{array}$ \\
\hline Uley South & $120\left(13.6 \times 10^{6}\right)$ & $56\left(6.3 \times 10^{6}\right)$ \\
\hline $\begin{array}{l}\text { Blue Lake } \\
\text { capture zone }\end{array}$ & $457\left(7.6 \times 10^{6}\right)$ & $95\left(1.6 \times 10^{6}\right)$ \\
\hline $\begin{array}{l}\text { Poocher } \\
\text { Swamp fresh } \\
\text { water bubble }\end{array}$ & $127.3\left(2.55 \times 10^{6}\right)$ & $14\left(0.28 \times 10^{6}\right)$ \\
\hline
\end{tabular}

N. Somaratne and

K. R. J. Smettem

Title Page

Abstract

Introduction

Conclusions

References

Tables

Figures

14

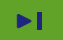

4

Back

Close

Full Screen / Esc

Printer-friendly Version

Interactive Discussion 


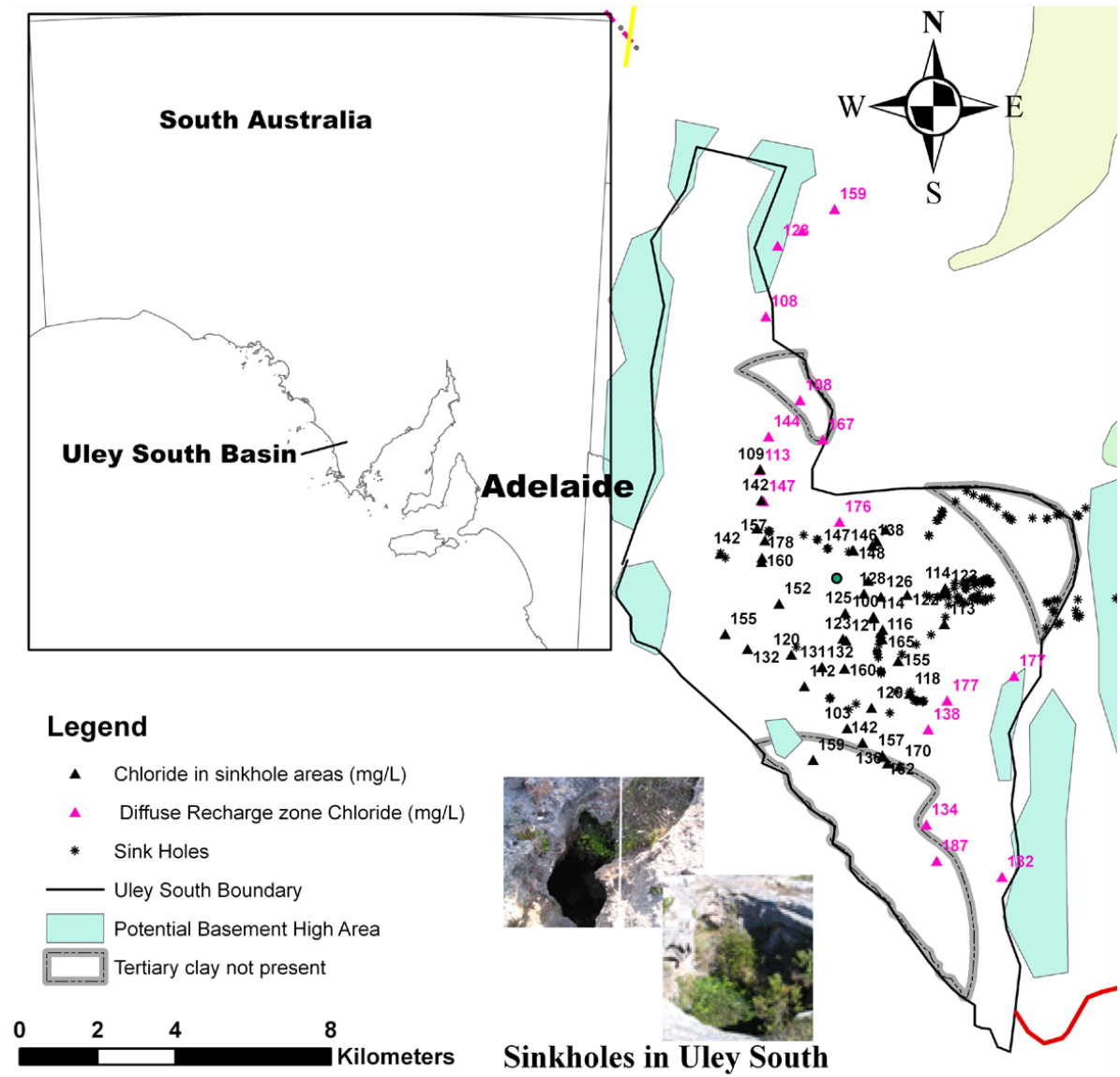

\section{HESSD}

11, 307-332, 2014

Generalized chloride mass balance method

N. Somaratne and K. R. J. Smettem

\section{Title Page}

\section{Back}

\section{Full Screen / Esc}

Printer-friendly Version

Interactive Discussion 


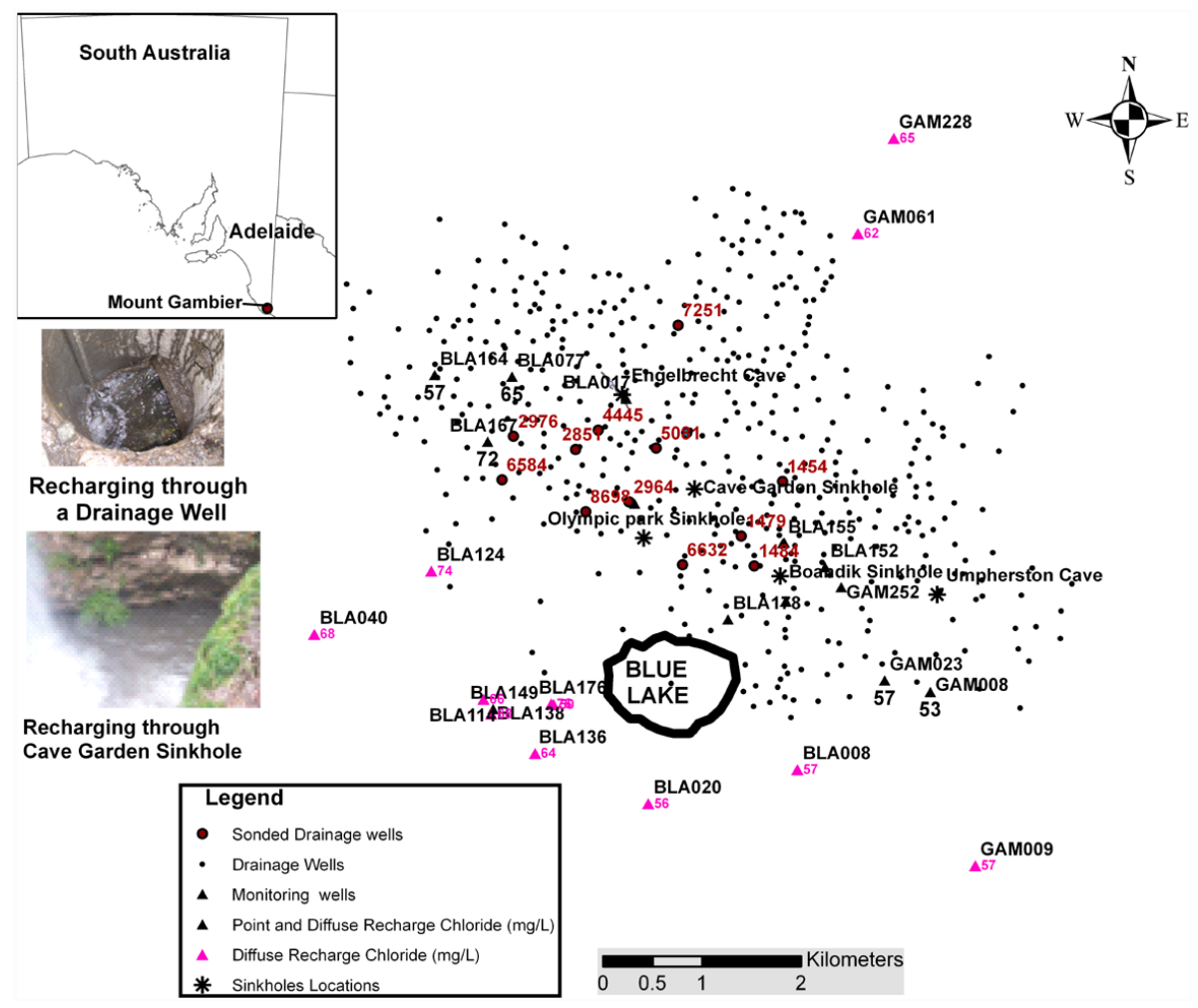

\section{HESSD}

11, 307-332, 2014

Generalized chloride

mass balance

method

N. Somaratne and

K. R. J. Smettem

\section{Title Page}

Abstract

Introduction

Conclusions

References

Tables

Figures

14

4

Back

\section{Full Screen / Esc}

Printer-friendly Version

Interactive Discussion 


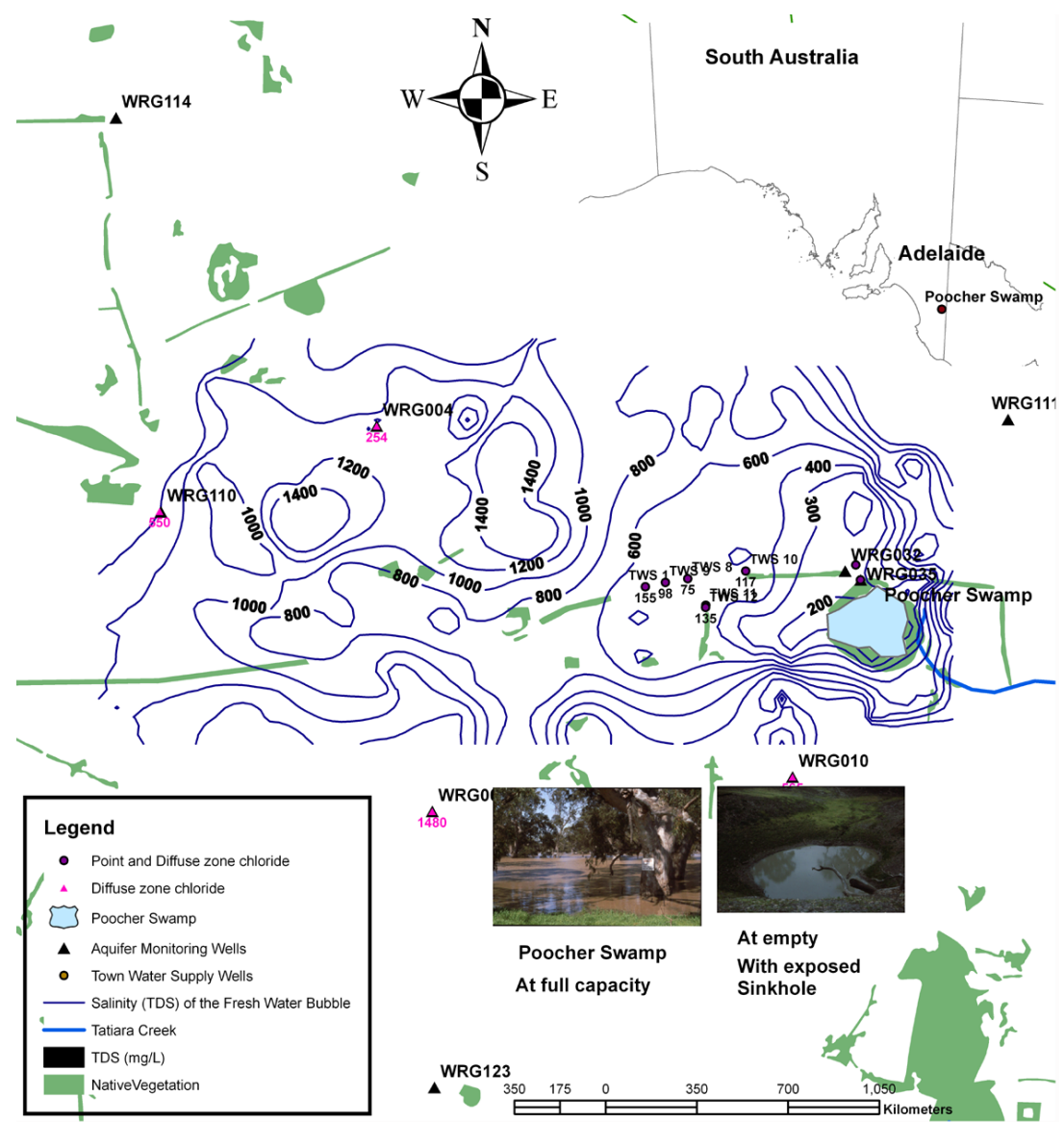

Fig. 3. Poocher Swamp fresh water bubble (Somaratne et al., 2013).
HESSD

$11,307-332,2014$

Generalized chloride mass balance method

N. Somaratne and K. R. J. Smettem

\section{Title Page}

Abstract Introduction

Conclusions References

Tables Figures

14 $>1$

$\triangleleft$

Back

Close

\section{Full Screen / Esc}

Printer-friendly Version

Interactive Discussion 


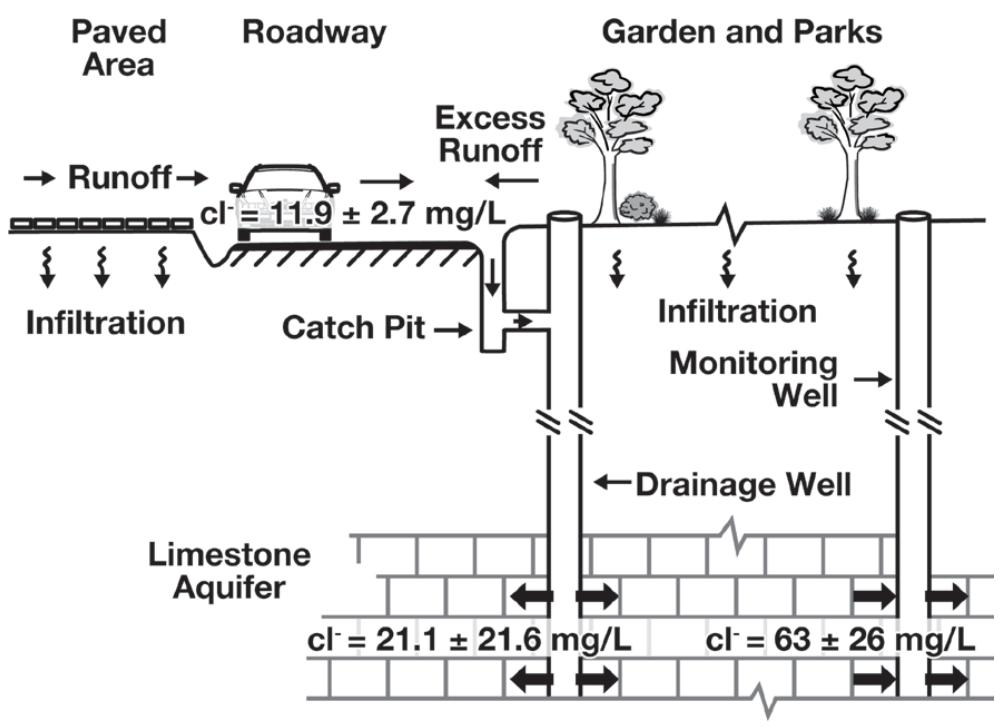

Fig. 4. Schematic diagram showing an example of differing chloride concentrations in drainage and aquifer monitoring wells.

\section{HESSD}

$11,307-332,2014$

Generalized chloride mass balance method

N. Somaratne and K. R. J. Smettem

\section{Title Page}

Abstract Introduction

Conclusions References

Tables Figures

14 -1

4

Back Close

Full Screen / Esc

Printer-friendly Version

Interactive Discussion 

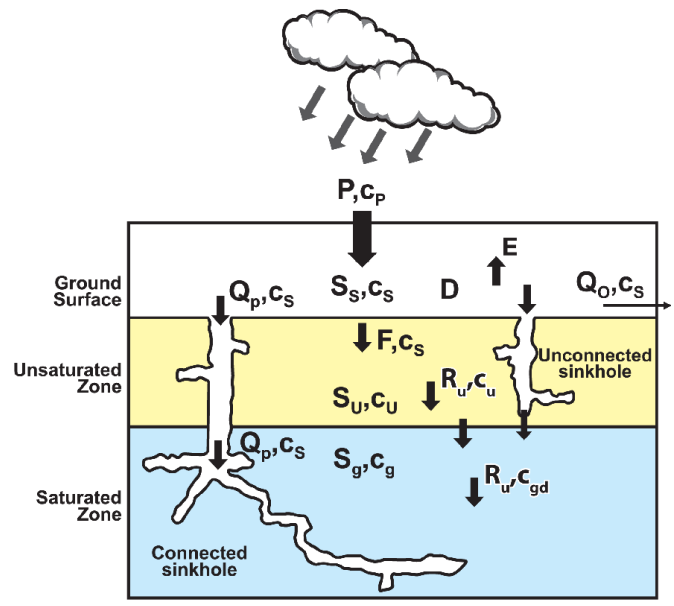

$S_{s}=$ Surface Storage (L)

$c_{\mathrm{s}}=$ Chloride concentration of the surface water $\left(\mathrm{ML}^{-3}\right)$

$\mathbf{P}=$ Average annual rainfall $\left(\mathrm{LT}^{-1}\right)$

$c_{\mathrm{p}}=$ Chloride concentration of the rainfall $\left(\mathrm{ML}^{-3}\right)$

D = Dry deposition $\left(M^{-1} \mathrm{~L}^{-2}\right)$

$\mathbf{E}=$ Evapotranspiration $\left(\mathrm{LT}^{-1}\right)$

$Q_{p}=$ Runoff to sinkholes $\left(L^{-1}\right)$

$Q_{0}=$ Runoff out from the catchment $\left(\mathrm{LT}^{-1}\right)$

$F=$ Infiltration into soil profile $\left(\mathrm{LT}^{-1}\right)$

$S_{\mathrm{u}}=$ Unsaturated zone storage $(\mathrm{L})$

$c_{u}=$ Chloride concentration in recharging water $\left(\mathrm{ML}^{-3}\right)$

$\mathbf{R}_{\mathrm{u}}=$ Diffuse recharge through the soil profile (LT ${ }^{-1}$ )

$S_{g}=$ Groundwater storage (L)

$c_{g}=$ Groundwater chloride concentration $\left(\mathrm{ML}^{-3}\right)$

$\mathbf{c}_{\mathbf{g d}}=$ Chloride concentration of groundwater in diffuse recharge zone $\left(\mathrm{ML}^{-3}\right)$

Fig. 5. Schematic diagram for applying chloride mass balance to a control volume.

\section{HESSD}

$11,307-332,2014$

Generalized chloride

mass balance

method

N. Somaratne and

K. R. J. Smettem

Title Page

Abstract

Introduction

Conclusions

References

Tables

Figures

14

1

4

Back

Close

Full Screen / Esc

Printer-friendly Version

Interactive Discussion 